\title{
Blood Flow Modeling in Coronary Arteries: A Review
}

\author{
Violeta Carvalho ${ }^{1}$, Diana Pinho ${ }^{1,2,3,4,+} \mathbb{D}$, Rui A. Lima ${ }^{1,2, * \mathbb{D}}$, José Carlos Teixeira ${ }^{1}$ and Senhorinha Teixeira ${ }^{5}$
}

1 MEtRICs Research Center, Mechanical Engineering Department, University of Minho, Campus de Azurém, 4800-058 Guimarães, Portugal; violeta.carvalho@dem.uminho.pt (V.C.); diana@ipb.pt (D.P.); jt@dem.uminho.pt (J.C.T.)

2 CEFT, Faculdade de Engenharia da Universidade do Porto (FEUP), R. Dr. Roberto Frias, 4200-465 Porto, Portugal

3 Research Centre in Digitalization and Intelligent Robotics (CeDRI), Instituto Politécnico de Bragança, Campus de Santa Apolónia, 5300-253 Bragança, Portugal

4 Center for MicroElectromechanical Systems (CMEMS-UMinho), University of Minho, Campus de Azurém, 4800-058 Guimarães, Portugal

5 ALGORITMI Centre (CAlg), University of Minho, 4800-058 Guimarães, Portugal; st@dps.uminho.pt

* Correspondence: rl@dem.uminho.pt

† Current Affiliation: INL-International Iberian Nanotechnology Laboratory, Av. Mestre José Veiga, 4715-330 Braga, Portugal; diana.pinho@inl.int.

\section{check for}

updates

Citation: Carvalho, V.; Pinho, D.; Lima, R.A.; Teixeira, J.C.; Teixeira, S. Blood Flow Modeling in Coronary Arteries: A Review. Fluids 2021, 6, 53. https://doi.org/10.3390/fluids6020053

Academic Editors: Fang-Bao Tian and Li Wang

Received: 29 November 2020

Accepted: 20 January 2021

Published: 23 January 2021

Publisher's Note: MDPI stays neutral with regard to jurisdictional claims in published maps and institutional affiliations.

Copyright: (c) 2021 by the authors. Licensee MDPI, Basel, Switzerland. This article is an open access article distributed under the terms and conditions of the Creative Commons Attribution (CC BY) license (https:/ / creativecommons.org/licenses/by/ $4.0 /)$.

\begin{abstract}
Atherosclerosis is one of the main causes of cardiovascular events, namely, myocardium infarction and cerebral stroke, responsible for a great number of deaths every year worldwide. This pathology is caused by the progressive accumulation of low-density lipoproteins, cholesterol, and other substances on the arterial wall, narrowing its lumen. To date, many hemodynamic studies have been conducted experimentally and/or numerically; however, this disease is not yet fully understood. For this reason, the research of this pathology is still ongoing, mainly, resorting to computational methods. These have been increasingly used in biomedical research of atherosclerosis because of their high-performance hardware and software. Taking into account the attempts that have been made in computational techniques to simulate realistic conditions of blood flow in both diseased and healthy arteries, the present review aims to give an overview of the most recent numerical studies focused on coronary arteries, by addressing the blood viscosity models, and applied physiological flow conditions. In general, regardless of the boundary conditions, numerical studies have been contributed to a better understanding of the development of this disease, its diagnosis, and its treatment.
\end{abstract}

Keywords: atherosclerosis; coronary arteries; hemodynamics; numerical methods

\section{Introduction}

Cardiovascular diseases are responsible for a critical number of deaths every year worldwide, accounting for nearly $31 \%$ of all deaths, most of which are associated with atherosclerosis, a disease that causes unusual hemodynamic conditions in arteries [1-3]. Briefly, atherosclerosis is a silent, multifactorial, and complex disease initiated when lipids and immune cells are accumulated in the arterial wall, resulting in the formation of a plaque $[4,5]$. This has been correlated to local biological, biomechanical, and systemic factors [6-8]. Among these factors, local hemodynamics has been indicated as the major cause [9-11]. In particular, wall shear stress (WSS) is a well-known predictor of coronary atherosclerosis progression. While regions of low wall shear stress have been commonly recognized as prone to plaque development, high values of WSS are related to plaque destabilization [12-16]. Moreover, a recent study has also proved that patients with COVID19 are at high risk for thrombotic arterial and venous occlusions. Considering the mortality rate caused by this virus itself until today and its relation with atherosclerosis development, this becomes an even more complex situation [17]. 
Although the presence of this pathology has quite serious damage regardless of the arteries affected, the situation is aggravated when this pathology develops in coronary arteries. When those are affected, the agglomeration of fatty materials creates an occlusion, which restricts the blood flow to the heart muscle leading to a decreased supply of blood, oxygen, and other vital nutrients fundamental for the proper functioning of this organ. Eventually, the reduced blood flow may cause chest pain or a heart attack if there is a complete blockage of the artery $[18,19]$. A common approach used to treat this pathology is balloon angioplasty and placement of an intracoronary stent. This allows restoring the blood flow keeping the artery open, nevertheless, the risk of restenosis is still present [20,21].

Considering the global impact of this disease, it is of utmost importance to obtain deeper knowledge about the blood flow hemodynamics. For this reason, extensive research has been done in this area, by applying either experimental and/or numerical methods. Although numerous experimental hemodynamic studies are found in the literature, by applying either in vitro [22-28], in vivo [29-33], or ex vivo [34-36] approaches, there are some drawbacks associated as reported elsewhere [19,37-41]. For this reason, lately, computational approaches have been the preferred method of several researchers [42-46]. These have become a valuable tool for evaluating and predicting the disease formation, and also for testing the performance of new devices for its treatment. By having the capability of constructing more realistic virtual models, getting fast and accurate results, and thoroughly testing different physiological conditions, some limitations of hemodynamic experimental techniques used can be overcome by the computational models [45,47-51]. However, this does not mean that those models can completely replace experimental tests since it is still quite challenging to perform realistic blood flow modeling [52].

Due to several advantages of using numerical simulations, computational atherosclerosis studies have gained popularity in recent years [53]. In general, to perform numerical simulations three main steps have to be accomplished, the pre-processing, the solver, and the post-processing. Firstly, it is necessary to define the geometry of the problem, followed by the mesh generation. Secondly, the fluid properties of blood, the flow physics model, and the boundary conditions are defined in order to solve the mathematical model. Finally, after the problem being solved, the results are analyzed. These steps are drafted as follows in Figure 1.

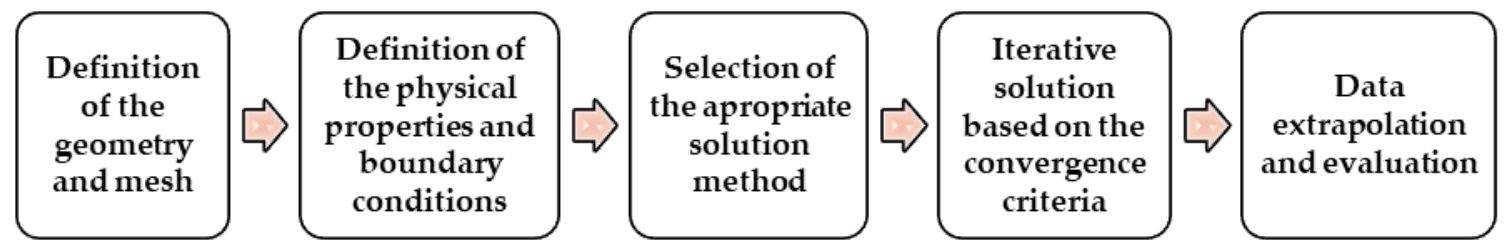

Figure 1. Main steps performed in numerical simulations.

Over the years, researchers have modeled blood flow within arteries by using different geometries, diverging in two directions, using either stenotic geometries with idealized shapes (e.g., half-sphere [54], ellipsoid [55], gaussian equation [56], cosine function [57], among others proposed by the authors themselves $[58,59]$ ) or realistic coronary artery models extracted from patient's medical data [60-65].

After defining the geometry, the blood properties have to be set to solve the problem accurately. Blood is a complex mixture of cells, proteins, lipoproteins, and ions which are transports nutrients and wastes. Due to the presence of red blood cells, the viscosity of blood is increased and affects the behavior of the fluid. Moreover, although considering the blood as a Newtonian fluid is generally accepted as a good approximation for large vessels, in the microcirculatory system, and also in the presence of stenosis, the assumption is not true. At these locations, the non-Newtonian behavior is more evident due to the ability of red blood cells to form aggregates, termed rouleaux, at low shear rates. Moreover, 
other aspects that should be taken into account are the cyclic nature of the heart pump, which creates pulsatile conditions, and also the elastic behavior observed in the arteries' wall [66-68].

Although the aforementioned characteristics of blood, namely, the vessel wall elasticity, non-Newtonian viscosity, and particles in the fluid, and body forces are physiologically relevant, the analysis of blood flow can be greatly simplified by neglecting some of the properties [68]. For this reason, in the literature, there is a vast diversity of articles that apply different boundary conditions to simulate blood flow, and attention must be taken since the performance of CFD models is directly dependent on the blood rheology, physiological flow conditions, mechanical properties of blood vessels, among other mechanical and biological factors set to solve the problem. In this regard, in the present paper, a review of the geometries, boundary conditions, and flow properties proposed by several authors for coronary models is provided by discussing and presenting the current knowledge on the advantages and also the drawbacks of blood viscosity models and physiological flow conditions available.

\section{Blood Flow Studies in Coronary Arteries}

Despite the progress done in experimental studies and blood flow measurement techniques, there are still some challenges associated with them [19]. For instance, in vitro WSS measurements are extremely difficult to perform and the velocity measurements have high associated errors. These, combined with other complications of directly measuring quantities of interest, have motivated the use of computer simulations to predict them in silico [69].

The earliest numerical detailed studies solving the flow problem in constricted tubes were conducted by Lee and Fung (1970) [70]. After that, other studies in this field conducted by Caro et al., (1971) [71], Glagov et al., (1989) [72], and Ku et al., (1985) [73] are important references in this area and should be highlighted. Ever since, CFD approaches have been progressively adopted by most researchers as the preferred technique for numerical modeling of hemodynamics. Owing to the continued growth of computational power, these have become an increasingly reliable tool for measuring biomechanical factors vital for clinical decision-making and surgical planning. However, the proper selection of the flow boundary conditions has to be done, otherwise, the findings can be considered uncertain, weak, and unrealistic [74]. In this regard, the different geometries, boundary conditions, and flow characteristics applied by some researchers in the last ten years are summarized in Table 1.

From the above-mentioned investigations, it can be seen that, regardless of the type of geometry, the majority of authors consider that the blood is a non-Newtonian fluid, usually approximated by the Carreau model, with a laminar behavior. Regarding the boundary conditions, in most cases, the wall is considered rigid, and at the inlet, a pulsatile velocity is applied. At the outlet, the condition set mainly depends on the study, but either the default conditions are maintained, or pressures are applied, time-dependent or constant values. 
Table 1. Numerical studies of hemodynamics and the respective assumptions for numerical simulations.

\begin{tabular}{|c|c|c|c|c|c|c|c|}
\hline \multirow{2}{*}{ Geometry } & \multirow{2}{*}{ Schematic Representation } & \multirow{2}{*}{ Modeling Approaches } & \multirow{2}{*}{ Fluid } & \multicolumn{3}{|c|}{ Boundary Conditions } & \multirow{2}{*}{ Authors } \\
\hline & & & & Wall & Inlet & Outlet & \\
\hline Idealized & & Laminar & $\begin{array}{l}\text { Non-Newtonian } \\
\text { (Carreau-Yasuda) }\end{array}$ & Rigid & $\begin{array}{l}\text { Time-dependent velocity } \\
\text { profile }\end{array}$ & Zero gauge pressure & Kashyap et al., (2020) [6] \\
\hline Idealized & & Laminar & Non-Newtonian (Cross model) & Rigid and Flexible & Constant inlet velocity & $\begin{array}{c}\text { Constant pressure outlet } \\
(10 \mathrm{kPa})\end{array}$ & Mulani et al., (2015) [57] \\
\hline Idealized & - & Laminar & Newtonian & Rigid and Flexible & $\begin{array}{l}\text { Time-dependent flowrate } \\
\text { profile }\end{array}$ & $\begin{array}{l}\text { Time-dependent pressure } \\
\text { profile }\end{array}$ & Wu et al., (2015) [58] \\
\hline Idealized & now & Laminar & Newtonian & Rigid & $\begin{array}{c}\text { Constant inlet velocity } \\
\text { (fully developed parabolic } \\
\text { profile) }\end{array}$ & $\begin{array}{l}\text { Constant pressure outlet } \\
(13 \mathrm{kPa})\end{array}$ & Kenjereš et al., (2019) [76] \\
\hline Idealized & & Laminar & Newtonian & Rigid & Constant inlet velocity & Zero gauge pressure & Carvalho et al., (2020) [47] \\
\hline Idealized & & $\mathrm{k}-\omega$ turbulent model & $\begin{array}{l}\text { Non-Newtonian (Carreau } \\
\text { model) }\end{array}$ & Rigid & $\begin{array}{c}\text { Spiral boundary } \\
\text { conditionwith a parabolic } \\
\text { velocity profile }\end{array}$ & Zero gauge pressure & Kabir et al., (2018) [77] \\
\hline Idealized & & $\mathrm{k}-\omega$ turbulent model (SST) & $\begin{array}{l}\text { Non-Newtonian (Carreau } \\
\text { model) }\end{array}$ & Rigid & $\begin{array}{l}\text { Time-dependent velocity } \\
\text { profile }\end{array}$ & Zero gauge pressure & Carvalho et al., (2020) [42] \\
\hline Idealized & & $\mathrm{k}-\omega$ turbulent model (SST) & $\begin{array}{l}\text { Non-Newtonian (Carreau } \\
\text { model) }\end{array}$ & Rigid & $\begin{array}{l}\text { Time-dependent velocity } \\
\text { profile }\end{array}$ & Zero gauge pressure & Carvalho et al., (2020) $[59,78]$ \\
\hline Idealized & & N.A ${ }^{1}$ & Newtonian & Flexible & $\begin{array}{l}\text { Time-dependent velocity } \\
\text { profile }\end{array}$ & $\begin{array}{l}\text { Time-dependent pressure } \\
\text { profile }\end{array}$ & Jahromi et al., (2019) [79] \\
\hline
\end{tabular}


Table 1. Cont.

\begin{tabular}{|c|c|c|c|c|c|c|c|}
\hline \multirow{2}{*}{ Geometry } & \multirow{2}{*}{ Schematic Representation } & \multirow{2}{*}{ Modeling Approaches } & \multirow{2}{*}{ Fluid } & \multicolumn{3}{|c|}{ Boundary Conditions } & \multirow{2}{*}{ Authors } \\
\hline & & & & Wall & Inlet & Outlet & \\
\hline Idealized & & Laminar & Newtonian & Rigid & $\begin{array}{l}\text { Time-dependent velocity } \\
\text { profile }\end{array}$ & $\begin{array}{l}\text { Flow partition implied in } \\
\text { Murray's law }\end{array}$ & Doutel et al., (2018) [11] \\
\hline $\begin{array}{l}\text { Patient- } \\
\text { specific }\end{array}$ & & Laminar & $\begin{array}{l}\text { Non-Newtonian (Generalized } \\
\text { power-law model) and } \\
\text { Newtonian }\end{array}$ & Rigid & $\begin{array}{l}\text { Time-dependent flow rate } \\
\text { profile }\end{array}$ & $\begin{array}{l}\text { Time-dependent pressure } \\
\text { profile }\end{array}$ & Chaichana et al., (2012) [60 \\
\hline $\begin{array}{l}\text { Patient- } \\
\text { specific }\end{array}$ & & Laminar & $\begin{array}{c}\text { Non-Newtonian (Carreau } \\
\text { model) }\end{array}$ & Rigid & $\begin{array}{l}\text { Time-dependent velocity } \\
\text { profile }\end{array}$ & $\begin{array}{l}\text { Time-dependent pressure } \\
\text { profile }\end{array}$ & Liu et al., (2015) [80] \\
\hline $\begin{array}{l}\text { Patient- } \\
\text { specific }\end{array}$ & & Laminar & Newtonian & Rigid and Flexible & $\begin{array}{l}\text { Time-dependent pressure } \\
\text { profile }\end{array}$ & Parabolic velocity profile & Siogkas et al., (2014) [81] \\
\hline $\begin{array}{l}\text { Patient- } \\
\text { specific }\end{array}$ & & N.A & Newtonian & Rigid & $\begin{array}{l}\text { Time-dependent pressure } \\
\text { profile }\end{array}$ & $\begin{array}{c}\text { Constant pressure outlet } \\
(9.85 \mathrm{kPa})\end{array}$ & Zhao et al., (2019) [82] \\
\hline
\end{tabular}


Table 1. Cont.

\begin{tabular}{|c|c|c|c|c|c|c|c|}
\hline \multirow{2}{*}{ Geometry } & \multirow{2}{*}{ Schematic Representation } & \multirow{2}{*}{ Modeling Approaches } & \multirow{2}{*}{ Fluid } & \multicolumn{3}{|c|}{ Boundary Conditions } & \multirow{2}{*}{ Authors } \\
\hline & & & & Wall & Inlet & Outlet & \\
\hline $\begin{array}{l}\text { Patient- } \\
\text { specific }\end{array}$ & & N.A & $\begin{array}{c}\text { Non-Newtonian (Power-law } \\
\text { model) }\end{array}$ & Rigid & $\begin{array}{c}\text { Time-dependent velocity } \\
\text { profile }\end{array}$ & Pressure outlet (N.A) & Zhang et al., (2020) [83] \\
\hline $\begin{array}{l}\text { Patient- } \\
\text { specific }\end{array}$ & & $\mathrm{k}-\omega$ turbulent model (SST) & $\begin{array}{l}\text { Non-Newtonian (Bird-Carreau } \\
\text { model) }\end{array}$ & Rigid & $\begin{array}{l}\text { Time-dependent velocity } \\
\text { profile }\end{array}$ & $\begin{array}{l}\text { Constant pressure outlet } \\
(10 \mathrm{kPa})\end{array}$ & Kamangar et al., (2019) [64] \\
\hline $\begin{array}{l}\text { Patient- } \\
\text { specific }\end{array}$ & & Laminar & Newtonian & Rigid & $\begin{array}{l}\text { Time-dependent flow rate } \\
\text { profile }\end{array}$ & $\begin{array}{l}\text { Two-Element Windkessel } \\
\text { Model }\end{array}$ & Lo et al., (2019) [84] \\
\hline
\end{tabular}


Table 1. Cont.

\begin{tabular}{|c|c|c|c|c|c|c|c|}
\hline \multirow{2}{*}{ Geometry } & \multirow{2}{*}{ Schematic Representation } & \multirow{2}{*}{ Modeling Approaches } & \multirow{2}{*}{ Fluid } & \multicolumn{3}{|c|}{ Boundary Conditions } & \multirow{2}{*}{ Authors } \\
\hline & & & & Wall & Inlet & Outlet & \\
\hline $\begin{array}{l}\text { Patient- } \\
\text { specific and } \\
\text { Idealized }\end{array}$ & & $\mathrm{k}-\omega$ turbulent model (SST) & $\begin{array}{l}\text { Non-Newtonian (Carreau } \\
\text { model) }\end{array}$ & Rigid & $\begin{array}{l}\text { Time-dependent velocity } \\
\text { profile }\end{array}$ & Outflow condition & Mahalingam et al., (2016) [86] \\
\hline $\begin{array}{l}\text { Patient- } \\
\text { specific and } \\
\text { Idealized }\end{array}$ & & N.A & $\begin{array}{l}\text { Non-Newtonian (Carreau } \\
\text { model) }\end{array}$ & Rigid & $\begin{array}{l}\text { Time-dependent velocity } \\
\text { profile }\end{array}$ & $\begin{array}{l}\text { Constant pressure outlet } \\
(10 \mathrm{kPa})\end{array}$ & Rabbi et al., (2020) [87] \\
\hline
\end{tabular}


Table 1. Cont.

\begin{tabular}{|c|c|c|c|c|c|c|c|}
\hline \multirow{2}{*}{ Geometry } & \multirow{2}{*}{ Schematic Representation } & \multirow{2}{*}{ Modeling Approaches } & \multirow{2}{*}{ Fluid } & \multicolumn{3}{|c|}{ Boundary Conditions } & \multirow{2}{*}{ Authors } \\
\hline & & & & Wall & Inlet & Outlet & \\
\hline & stenosis & & & & & & \\
\hline $\begin{array}{l}\text { Patient- } \\
\text { specific and } \\
\text { Idealized }\end{array}$ & & Laminar & Newtonian & Rigid & $\begin{array}{l}\text { Constant inlet mass flow } \\
\text { and Time-dependent flow } \\
\text { rate }\end{array}$ & Zero gauge pressure & Malota et al., (2018) [88 \\
\hline
\end{tabular}




\subsection{Geometrical Parameters and Stenosis Severity}

Before studying directly stenotic coronary arteries, some authors have dedicated their time to study the effect of geometrical parameters, such as the branch curvatures, tortuosities, and the angulations of the arteries, and relating them to the development of atherosclerosis, by resorting to idealized geometries, or the combination of patient-specific models with idealized ones $[6,87,89]$. In general, regardless of the type of geometry, it has been shown that there is a direct correlation between wide angulation in the coronary artery branches and hemodynamic changes, such as disturbed flow and low WSS, possibly inducing the development of atherosclerosis $[87,89]$. Although consistent observations between idealized and patient-specific models have been demonstrated by Chaichana et al., (2011) [89], the same is not true when talking about the arteries' curvature and tortuosity, since small variations can lead to different hemodynamic simulated results [6]. It was shown that the specific curvature of each branch of the coronary bifurcation affects the hemodynamics of the remaining three branches, which can cause an increase in atherosusceptibility [6]. In view of this, it can be verified that the selection of the geometrical parameters of the artery model plays an important role and can lead to different hemodynamic results.

Nevertheless, when the aim is to investigate the effect of stenosis severity, the results presented in the literature have shown to be in good agreement independently of the model used, idealized, or patient-specific. Generally, an increase in the velocity and WSS at the stenosis throat is observed. This increased WSS can disturb the plaque formed and lead to plaque rupture, and consequently to heart failure. Besides the WSS, other shear stress indices have been studied such as the time average wall shear stress (TAWSS), and the oscillatory stress index (OSI). While the TAWSS has the same trend as WSS, the OSI distribution has a maximum value in the region downstream of the stenosis. Moreover, in this location, the prevalence of recirculation zones is also verified $[60,64,75,86,90,91]$. Both high OSI, low WSS, and disturbed flows in the post stenotic section are important factors that can promote the formation of atherosclerotic plaques [59,68,92].

A different way to study the effect of stenosis in blood flow hemodynamics was addressed by Doutel et al., (2018) [93]. They developed a methodology to create threedimensional irregular stenosis with different degrees of occlusion in artery models for both numerical and in vitro hemodynamic studies. This methodology is quite interesting since it allows the creation of realistic stenosis in a fast way for hemodynamic studies. Furthermore, the authors proved that the irregular shape of the stenosis and their specific morphology affects the flow field, creating diverse values of WSS for each case.

\subsection{Newtonian and Non-Newtonian Assumptions}

Besides the effect of stenosis, several studies have emphasized the importance of considering the non-Newtonian behavior of blood and selecting the proper model to better represent the in vivo conditions $[56,94]$. An interesting study was undertaken by Razavi et al., (2011) [56], in which six non-Newtonian models and a Newtonian model were compared. The data obtained showed that the power-law model produces higher deviations in comparison with other models, overstating the non-Newtonian behavior, regarding the velocity and WSS values. On the other hand, the generalized power-law and modified-Casson models are more similar to the Newtonian state, though, they underestimate the non-Newtonian behavior. In contrast to the previous models, the Carreau and Carreau-Yasuda models represented moderate IG values (cut-off value above which flow can be assumed as non-Newtonian), demonstrating to be the suitable models to mimic the blood behavior. Other authors have also compared Newtonian and non-Newtonian models. Chaichana et al., (2012) [60] compared the effect of the non-Newtonian powerlaw generalized model with a Newtonian fluid; however, similar results were obtained for both cases, in terms of velocity fields and WSS measurements. On the other hand, Gaudio et al. (2018) [91] compared the Newtonian and non-Newtonian Carreau-Yasuda model. Their results showed that the velocity for the Carreau-Yasuda model is slightly 
lower when compared to the Newtonian model, but the non-Newtonian effects are most important in shear stress indices distributions. Carvalho et al., (2020) [78] have similar results; however, they used the Carreau non-Newtonian model. Another interesting study was performed by Pinto et al., (2020) [95]. They investigated several viscoelastic models, namely the Generalized Oldroyd-B (GOB) model, the Multi-mode Giesekus and Simplified Phan-Thien/Tanner (sPTT) models in order to conclude which model is the most accurate to simulate the blood flow, and compared those with the Carreau model and also with a Newtonian model. The authors verified that the non-linear viscoelastic multi-mode models (Giesekus and sPTT) cause an overall reduction of the velocity in regions of higher velocity gradients. In general, the researchers concluded that the sPTT model should be the preferred option since the Giesekus model introduces the second normal stress difference, which so far has not been reported for blood.

\subsection{Turbulence Modeling and Wall Assumptions}

Although various investigations consider the blood flow as laminar, due to the pulsatile nature of blood flow through arteries, and the presence of stenosis, the transition from laminar to turbulent flow condition can occur. For this reason, some authors have explored some turbulent models in computational simulations [42,59,64,77,78,86,96]. By observing Table 1 it can be seen that the majority uses or the standard k- $\omega$ or the k- $\omega$ SST turbulent model. The main difference between these two models is that the SST model accounts for the laminar to turbulent transition, and it seems to be the most suitable for blood flow studies [64,97]. However, in a study conducted by Straatman et al., (2016) [97], both models were compared with experimental data, and the k- $\omega$ SST turbulent model provided the best overall results.

Furthermore, hemodynamic studies mainly assume the wall to be rigid, however, over the years, fluid-structure interaction (FSI) has received increasing interest due to its ability to simultaneously model blood flow and arterial wall deformations [79,81,98-101]. Among the several investigations that have emerged in this area, one of the most cited works in the literature was performed by Torii et al., (2009) [99], wherein the effects of compliance in WSS calculations were studied. Although more recent studies have been conducted to evaluate if there are significant differences between flexible and rigid walls, the main results are in good agreement. It is stated that there are negligible differences in TAWSS and OSI values, although, in the distal region of the artery, differences in instantaneous WSS profiles and velocity measurements were perceptible [57,99]. Regardless of the interesting results obtained in the literature, since arteries have a high degree of stiffness, in most cases, the effects of elasticity are very small, and thus, an assumption of rigid tube flow is reasonable [68].

\section{Conclusions and Future Perspectives}

Due to the great progress that has been made recently in the development of CFD methods, these have become extremely fundamental for hemodynamic studies, allowing researchers to obtain a better understanding of atherosclerosis in a rapid and accurate fashion. However, there are still unsolved challenges that have to be addressed in future hemodynamic studies. In the present review, the application of computational simulations by using different physiological conditions of blood flow, several rheological models, and boundary conditions, were discussed.

Although huge advancements have been made in imaging techniques to obtain patientspecific images, this step is time-consuming, and it is still a challenging task for all researchers. For this reason, nowadays, idealized models continue to be widely used by researchers, since these allow to obtain important and relevant results, without requiring much computational time and without the need to collect the medical images, which is highly time-consuming. In this regard, a promising study was proposed by Doutel et al., (2018) [93] wherein artificial, but realistic stenosis can be generated. 
It was also noted that, although the modelling of blood as a Newtonian fluid is a good approximation for large vessels with high shear rates, the assumption of non-Newtonian behavior of blood flow has been increasingly used in the presence of stenosis. From the overall studies, the most used models are the Carreau and the Carreau-Yasuda, and these have also been indicated as the most appropriate to simulate the blood rheology by Razavi et al., (2011) [56]. Nevertheless, currently, one cannot say which is the right model, because there is not yet enough evidence in the literature to prove which model fully expresses the complex nature of blood rheology and its dependence on many biological factors [50]. Accordingly, it is of great importance to obtain proper models for CFD analysis that take into account the non-Newtonian behavior of blood. For this purpose, more experimental studies are needed. Regarding the boundary conditions, few studies have evaluated the impact of using different inlet and outlet boundary conditions [74,102], and therefore, it would be interesting, in future studies, to investigate what are the profiles more adequate to study the blood flow behavior in coronary arteries.

Despite the great efforts that have been made so far, the blood has been mainly modeled as a single-phase fluid. However, blood is a mixture of plasma, red blood cells, white blood cells, and platelets. Therefore, the consideration of multiphase models is of great importance when modeling atherosclerotic lesions. Although some studies have already applied these models $[42,83,103-105]$, the research is still in the beginning. Moreover, it should be also noted that the use of these models is a promising option for studying nanoparticle-mediated targeted drug delivery treatment of atherosclerosis. In this context, a promising study was conducted by Zhang et al., (2020) [83]. The authors used an Eulerian-Lagrangian approach coupled with FSI to investigate the impact of plaque morphology on magnetic nanoparticles targeting under the action of an external field.

Due to the continuous improvements acquired in computational methods, in the following years more amazing and complex hemodynamic studies will be performed. The work of Zhao et al., (2019) [82] should be highlighted since their numerical approach has a great potential to achieve more realistic simulations. They have simulated $4 \mathrm{D}$ hemodynamic profiles of time-resolved blood flow. The results proved that these simulations can provide extensive information about blood flow, both qualitatively and quantitatively that may be advantageous for future investigations of clinical diagnosis and treatment of atherosclerosis.

To conclude, although computational methods have been extensively used for atherosclerosis investigations in recent years, they are expected to become more popular and more effective to simulate the blood flow in the cardiovascular system, and consequently, they will promote medical innovation at an affordable cost. However, to this end, active collaborations between engineers and medical staff are needed to assure the successful application of this technique in atherosclerosis treatment.

Author Contributions: Conceptualization, V.C. and S.T.; Writing-Original Draft Preparation, V.C.; Writing-Review and Editing, V.C., D.P., R.A.L., J.C.T. and S.T.; Supervision, R.A.L. and S.T.; Funding Acquisition, J.C.T., R.A.L. and S.T. All authors have read and agreed to the published version of the manuscript.

Funding: This work was supported through the R\&D Units Project Scope: UIDB/00319/2020, UIDB/04077/2020, NORTE-01-0145-FEDER-030171, and NORTE-01-0145-FEDER-029394, funded by COMPETE2020, NORTE 2020, PORTUGAL 2020, and FEDER.

Conflicts of Interest: The authors declare no conflict of interest.

\section{References}

1. World Health Organization (WHO). Cardiovasc. Dis. Fact Sheet No.317, 2017. Available online: https://www.who.int/nmh/ publications/fact_sheet_cardiovascular_en.pdf (accessed on 20 January 2021).

2. Haverich, A.; Boyle, E.C. Atherosclerosis Pathogenesis and Microvascular Dysfunction, 1st ed.; Springer: New York, NY, USA, 2019; ISBN 9783030202446.

3. Libby, P.; Buring, J.E.; Badimon, L.; Hansson, G.K.; Deanfield, J.; Bittencourt, M.S.; Tokgözoğlu, L.; Lewis, E.F. Atherosclerosis. Nat. Rev. Dis. Prim. 2019, 5, 1-18. [CrossRef] [PubMed] 
4. Badimon, L.; Vilahur, G. Thrombosis formation on atherosclerotic lesions and plaque rupture. J. Intern. Med. 2014, $276,618-632$. [CrossRef] [PubMed]

5. Lusis, A.J. Atherosclerosis. Nature 2000, 407, 233-241. [CrossRef] [PubMed]

6. Kashyap, V.; Arora, B.B.; Bhattacharjee, S. A computational study of branch-wise curvature in idealized coronary artery bifurcations. Appl. Eng. Sci. 2020, 4, 100027. [CrossRef]

7. Sun, Y.; Guan, X. Autophagy: A new target for the treatment of atherosclerosis. Front. Lab. Med. 2018, 2, 68-71. [CrossRef]

8. Carpenter, H.J.; Gholipour, A.; Ghayesh, M.H.; Zander, A.C.; Psaltis, P.J. A review on the biomechanics of coronary arteries. Int. J. Eng. Sci. 2020, 147, 103201. [CrossRef]

9. Lopes, D.; Puga, H.; Teixeira, J.; Lima, R. Blood flow simulations in patient-specific geometries of the carotid artery: A systematic review. J. Biomech. 2020, 111, 110019. [CrossRef]

10. Zaromytidou, M.; Siasos, G.; Coskun, A.U.; Lucier, M.; Antoniadis, A.P.; Papafaklis, M.I.; Koskinas, K.C.; Andreou, I.; Feldman, C.L.; Stone, P.H. Intravascular hemodynamics and coronary artery disease: New insights and clinical implications. Hell. J. Cardiol. 2016, 57, 389-400. [CrossRef]

11. Doutel, E.; Carneiro, J.; Campos, J.B.L.M.; Miranda, J.M. Experimental and numerical methodology to analyze flows in a coronary bifurcation. Eur. J. Mech. B Fluids 2018, 67, 341-356. [CrossRef]

12. Nisco, G.D.; Hoogendoorn, A.; Chiastra, C.; Gallo, D.; Kok, A.M.; Morbiducci, U.; Wentzel, J.J. The impact of helical flow on coronary atherosclerotic plaque development. Atherosclerosis 2020, 1-8. [CrossRef]

13. Samady, H.; Eshtehardi, P.; McDaniel, M.C.; Suo, J.; Dhawan, S.S.; Maynard, C.; Timmins, L.H.; Quyyumi, A.A.; Giddens, D.P. Coronary artery wall shear stress is associated with progression and transformation of atherosclerotic plaque and arterial remodeling in patients with coronary artery disease. Circulation 2011, 124, 779-788. [CrossRef] [PubMed]

14. Han, D.; Starikov, A.; Hartaigh, B.; Gransar, H.; Kolli, K.K.; Lee, J.H.; Rizvi, A.; Baskaran, L.; Schulman-Marcus, J.; Lin, F.Y.; et al. Relationship between endothelial wall shear stress and high-risk atherosclerotic plaque characteristics for identification of coronary lesions that cause ischemia: A direct comparison with fractional flow reserve. J. Am. Heart Assoc. 2016, 5, 1-10. [CrossRef] [PubMed]

15. Siasos, G.; Sara, J.D.; Zaromytidou, M.; Park, K.H.; Coskun, A.U.; Lerman, L.O.; Oikonomou, E.; Maynard, C.C.; Fotiadis, D.; Stefanou, K.; et al. Local Low Shear Stress and Endothelial Dysfunction in Patients With Nonobstructive Coronary Atherosclerosis. J. Am. Coll. Cardiol. 2018, 71, 2092-2102. [CrossRef] [PubMed]

16. Soulis, J.V.; Fytanidis, D.K.; Seralidou, K.V.; Giannoglou, G.D. Wall shear stress oscillation and its gradient in the normal left coronary artery tree bifurcations. Hippokratia 2014, 18, 12-16. [PubMed]

17. Zuo, Y.; Estes, S.K.; Ali, R.A.; Gandhi, A.A.; Yalavarthi, S.; Shi, H.; Sule, G.; Gockman, K.; Madison, J.A.; Zuo, M.; et al. Prothrombotic autoantibodies in serum from patients hospitalized with COVID-19. Sci. Transl. Med. 2020, 3876, 1-17. [CrossRef]

18. Pandey, R.; Kumar, M.; Majdoubi, J.; Rahimi-Gorji, M.; Srivastav, V.K. A review study on blood in human coronary artery: Numerical approach. Comput. Methods Program. Biomed. 2020, 187, 105243. [CrossRef]

19. Carvalho, V.; Maia, I.; Souza, A.; Ribeiro, J.; Costa, P.; Puga, H.; Teixeira, S.F.C.F.; Lima, R.A. In vitro stenotic arteries to perform blood analogues flow visualizations and measurements: A Review. Open Biomed. Eng. J. 2020, 14, 87-102. [CrossRef]

20. LaDisa, J.F.; Olson, L.E.; Douglas, H.A.; Warltier, D.C.; Kersten, J.R.; Pagel, P.S. Alterations in regional vascular geometry produced by theoretical stent implantation influence distributions of wall shear stress: Analysis of a curved coronary artery using $3 \mathrm{D}$ computational fluid dynamics modeling. Biomed. Eng. Online 2006, 5, 1-11. [CrossRef]

21. Griggs, R.; Wing, E.F.G. Cecil Essentials of Medicine, 9th ed.; Elsevier: New York, NY, USA, 2016; ISBN 9781437718997.

22. Kabinejadian, F.; Ghista, D.N.; Su, B.; Kaabi Nezhadian, M.; Chua, L.P.; Yeo, J.H.; Leo, H.L. In vitro measurements of velocity and wall shear stress in a novel sequential anastomotic graft design model under pulsatile flow conditions. Med. Eng. Phys. 2014, 36, 1233-1245. [CrossRef]

23. Hewlin, R.L.; Kizito, J.P. Development of an Experimental and Digital Cardiovascular Arterial Model for Transient Hemodynamic and Postural Change Studies: "A Preliminary Framework Analysis". Cardiovasc. Eng. Technol. 2018, 9. [CrossRef]

24. Park, S.M.; Min, Y.U.; Kang, M.J.; Kim, K.C.; Ji, H.S. In vitro hemodynamic study on the stenotic right coronary artery using experimental and numerical analysis. J. Mech. Med. Biol. 2010, 10, 695-712. [CrossRef]

25. Souza, A.; Souza, M.S.; Pinho, D.; Agujetas, R.; Ferrera, C.; Lima, R.; Puga, H.; Ribeiro, J. 3D Manufacturing of Intracranial aneurysm biomodels for flow visualizations: A low-cost fabrication process. Mech. Res. Commun. 2020, 107, 103535. [CrossRef]

26. Bento, D.; Lopes, S.; Maia, I.; Lima, R.; Miranda, J.M. Bubbles moving in blood flow in a microchannel network: The effect on the local hematocrit. Micromachines 2020, 11, 344. [CrossRef] [PubMed]

27. Pinho, D.; Carvalho, V.; Gonçalves, I.M.; Teixeira, S.; Lima, R. Visualization and measurements of blood cells flowing in microfluidic systems and blood rheology: A personalized medicine perspective. J. Pers. Med. 2020, 10, 249. [CrossRef] [PubMed]

28. Carvalho, V.; Sousa, P.; Pinto, V.; Ribeiro, R.; Costa, P.; Teixeira, S.F.C.F.; Lima, R.A. Hemodynamic studies in coronary artery models manufactured by 3D printing. In Proceedings of the International Conference Innovation in Engineering, Guimarães, Portugal, 28-30 June 2021. accepted.

29. Stepniak, K.; Ursani, A.; Paul, N.; Naguib, H. Development of a phantom network for optimization of coronary artery disease imaging using computed tomography. Biomed. Phys. Eng. Express 2019, 5, 45019. [CrossRef]

30. Sjostrand, S.; Widerstrom, A.; Ahlgren, A.R.; Cinthio, M. Design and fabrication of a conceptual arterial ultrasound phantom capable of exhibiting longitudinal wall movement. IEEE Trans. Ultrason. Ferroelectr. Freq. Control 2017, 64, 11-18. [CrossRef] 
31. Papathanasopoulou, P.; Zhao, S.; Köhler, U.; Robertson, M.B.; Long, Q.; Hoskins, P.; Xu, X.Y.; Marshall, I. MRI measurement of time-resolved wall shear stress vectors in a carotid bifurcation model, and comparison with CFD predictions. J. Magn. Reson. Imaging 2003, 17, 153-162. [CrossRef]

32. Chayer, B.; Hoven, M.; Cardinal, M.-H.; Hongliang, L.; Lopata, R.; Cloutier, G. Atherosclerotic carotid bifurcation phantoms with stenotic soft inclusion for ultrasound flow and vessel wall elastography imaging. Phys. Med. Biol. 2019, 64, 95025. [CrossRef]

33. Goudot, G.; Poree, J.; Pedreira, O.; Khider, L.; Julia, P.; Alsac, J.; Laborie, E.; Mirault, T.; Tanter, M.; Messas, E.; et al. Wall Shear Stress Measurement by Ultrafast Vector Flow Imaging for Atherosclerotic Carotid Stenosis. Eur. Heart J. 2019, 40. [CrossRef]

34. Karimi, A.; Navidbakhsh, M.; Shojaei, A.; Faghihi, S. Measurement of the uniaxial mechanical properties of healthy and atherosclerotic human coronary arteries. Mater. Sci. Eng. C 2013, 33, 2550-2554. [CrossRef]

35. Karimi, A.; Navidbakhsh, M.; Shojaei, A.; Hassani, K.; Faghihi, S. Study of plaque vulnerability in coronary artery using Mooney-Rivlin model: A combination of finite element and experimental method. Biomed. Eng. Appl. Basis Commun. 2014, 26, 1-7. [CrossRef]

36. Santamore, W.; Walinsky, P.; Bove, A.; Cox, R.; Carey, R.A.; Spann, J.F. The effects of vasoconstriction on experimental coronary artery stenosis. Am. Heart J. 1980, 100, 852-858. [CrossRef]

37. Friedman, M.H.; Giddens, D.P. Blood flow in major blood vessels-Modeling and experiments. Ann. Biomed. Eng. 2005, 33, 1710-1713. [CrossRef] [PubMed]

38. Rezvan, A.; Ni, C.W.; Alberts-Grill, N.; Jo, H. Animal, in vitro, and ex vivo models of flow-dependent atherosclerosis: Role of oxidative stress. Antioxid. Redox Signal. 2011, 15, 1433-1448. [CrossRef] [PubMed]

39. Yazdi, S.G.; Geoghegan, P.H.; Docherty, P.D.; Jermy, M.; Khanafer, A. A Review of Arterial Phantom Fabrication Methods for Flow Measurement Using PIV Techniques. Ann. Biomed. Eng. 2018, 46, 1697-1721. [CrossRef]

40. Fröhlich, E.; Salar-behzadi, S. Toxicological Assessment of Inhaled Nanoparticles: Role of in Vivo, ex Vivo, in Vitro, and in Silico Studies. Int. J. Mol. Sci. 2014, 15, 4795-4822. [CrossRef]

41. Rodrigues, R.; Sousa, P.; Gaspar, J.; Bañobre-López, M.; Lima, R.; Minas, G. Organ-on-a-chip: A Preclinical Microfluidic Platform for the Progress of Nanomedicine. Small 2020, 1-19. [CrossRef]

42. Carvalho, V.; Rodrigues, N.; Ribeiro, R.; Costa, P.; Teixeira, J.C.F.; Lima, R.; Teixeira, S.F.C.F. Hemodynamic study in 3D printed stenotic coronary artery models: Experimental validation and transient simulation. Comput. Methods Biomech. Biomed. Eng. 2020, 1-14. [CrossRef]

43. Pandey, R.; Kumar, M.; Srivastav, V.K. Numerical computation of blood hemodynamic through constricted human left coronary artery: Pulsatile simulations. Comput. Methods Program. Biomed. 2020, 197, 105661. [CrossRef]

44. Lopes, D.; Puga, H.; Teixeira, J.C.; Teixeira, S.F. Influence of arterial mechanical properties on carotid blood flow: Comparison of CFD and FSI studies. Int. J. Mech. Sci. 2019, 160, 209-218. [CrossRef]

45. Elhanafy, A.; Elsaid, A.; Guaily, A. Numerical investigation of hematocrit variation effect on blood flow in an arterial segment with variable stenosis degree. J. Mol. Liq. 2020, 313, 113550. [CrossRef]

46. Carvalho, V.; Carneiro, F.; Ferreira, A.C.; Gama, V.; Teixeira, J.C.F.; Teixeira, S.F.C.F. Numerical study of the unsteady flow in simplified and realistic iliac bifurcation models. Comput. Methods Biomech. Biomed. Engin. 2021. under review.

47. Carvalho, V.; Rodrigues, N.; Ribeiro, R.; Costa, P.F.; Lima, R.A.; Teixeira, S.F.C.F. 3D Printed Biomodels for Flow Visualization in Stenotic Vessels: An Experimental and Numerical Study. Micromachines 2020, 11, 549. [CrossRef]

48. Versteeg, H.K.; Malalasekera, W. An Introduction to Computational Fluid Dynamics: The Finite Volume Method, 2nd ed.; Prentice Hall: Upper Saddle River, NJ, USA, 2007; ISBN 9780131274983.

49. Hoving, A.M.; de Vries, E.E.; Mikhal, J.; de Borst, G.J.; Slump, C.H. A Systematic Review for the Design of In Vitro Flow Studies of the Carotid Artery Bifurcation. Cardiovasc. Eng. Technol. 2019, 11, 111-127. [CrossRef] [PubMed]

50. Yilmaz, F.; Gundogdu, M.Y. A critical review on blood flow in large arteries; relevance to blood rheology, viscosity models, and physiologic conditions. Korea Aust. Rheol. J. 2008, 20, 197-211.

51. Lee, J.; Smith, N.P. The multi-scale modelling of coronary blood flow. Ann. Biomed. Eng. 2012, 40, 2399-2413. [CrossRef]

52. Lieber, B.B.; Siebes, M.; Yamaguchi, T. Correlation of hemodynamic events with clinical and pathological observations. Ann. Biomed. Eng. 2005, 33, 1695-1703. [CrossRef]

53. Zhang, J.-M.; Zhong, L.; Su, B.; Wan, M.; ShyaYap, J.; Tham, J.P.L.; Poh Chua, L.; Ghista, D.N.; San Tan, R. Perspective on CFD studies of coronary artery disease lesions and hemodynamics: A review Jun-Mei. Int. J. Numer. Method. Biomed. Eng. 2014, 30, 659-680. [CrossRef]

54. Sriyab, S. Mathematical Analysis of Non-Newtonian Blood Flow in Stenosis Narrow Arteries. Comput. Math. Methods Med. 2014, 2014, 479152. [CrossRef]

55. Chen, C.X.; Ding, Y.; Gear, J.A. Numerical simulation of atherosclerotic plaque growth using two-way fluid-structural interaction. ANZIAM J. 2012, 53, 277. [CrossRef]

56. Razavi, A.; Shirani, E.; Sadeghi, M.R. Numerical simulation of blood pulsatile flow in a stenosed carotid artery using different rheological models. J. Biomech. 2011, 44, 2021-2030. [CrossRef] [PubMed]

57. Mulani, S.S.; Jagad, P.I. Analysis of the Effects of Plaque Deposits on the Blood Flow through Human Artery. Int. Eng. Res. J. 2015, 41, 2319-3182. 
58. Wu, J.; Liu, G.; Huang, W.; Ghista, D.N.; Wong, K.K.L. Transient blood flow in elastic coronary arteries with varying degrees of stenosis and dilatations: CFD modelling and parametric study. Comput. Methods Biomech. Biomed. Eng. 2015, 18, $1835-1845$. [CrossRef]

59. Carvalho, V.; Rodrigues, N.; Lima, R.A.; Teixeira, S.F.C.F. Modeling blood pulsatile turbulent flow in stenotic coronary arteries. Int. J. Biol. Biomed. Eng. 2020, 14, 1998-4510. [CrossRef]

60. Chaichana, T.; Sun, Z.; Jewkes, J. Computational Fluid Dynamics Analysis of the Effect of Plaques in the Left Coronary Artery. Comput. Math. Methods Med. 2012, 2012, 504367. [CrossRef]

61. Shanmugavelayudam, S.K.; Rubenstein, D.A.; Yin, W. Effect of geometrical assumptions on numerical modeling of coronary blood flow under normal and disease conditions. J. Biomech. Eng. 2010, 132, 1-8. [CrossRef]

62. Chaichana, T.; Sun, Z.; Jewkes, J. Hemodynamic impacts of various types of stenosis inthe left coronary artery bifurcation: A patient-specific analysis. Phys. Med. 2013, 29, 447-452. [CrossRef]

63. Dabagh, M.; Takabe, W.; Jalali, P.; White, S.; Jo, H. Hemodynamic features in stenosed coronary arteries: CFD analysis based on histological images. J. Appl. Math. 2013, 2013, 11. [CrossRef]

64. Kamangar, S.; Salman Ahmed, N.J.; Badruddin, I.A.; Al-Rawahi, N.; Husain, A.; Govindaraju, K.; Yunus Khan, T.M. Effect of stenosis on hemodynamics in left coronary artery based on patient-specific CT scan. Biomed. Mater. Eng. 2019, 30, 463-473. [CrossRef]

65. Kim, H.J.; Vignon-Clementel, I.E.; Coogan, J.S.; Figueroa, C.A.; Jansen, K.E.; Taylor, C.A. Patient-specific modeling of blood flow and pressure in human coronary arteries. Ann. Biomed. Eng. 2010, 38, 3195-3209. [CrossRef]

66. Rubenstein, D.A.; Yin, W.; Frame, M. Biofluid Mechanics, 2nd ed.; Elsevier: New York, NY, USA, $2015 ;$ ISBN 9780128009444.

67. Formaggia, L.; Perktold, K.; Quarteroni, A. Cardiovascular Mathematics- Modeling and Simulation of the Circulatory System, 1st ed.; Springer: New York, NY, USA, 2009; Volume 53, ISBN 9788578110796.

68. Ku, D. Blood flow in arteries. Annu. Rev. Fluid Mech. 1997, 29, 399-434. [CrossRef]

69. Kissas, G.; Yang, Y.; Hwuang, E.; Witschey, W.R.; Detre, J.A.; Perdikaris, P. Machine learning in cardiovascular flows modeling: Predicting arterial blood pressure from non-invasive 4D flow MRI data using physics-informed neural networks. Comput. Methods Appl. Mech. Eng. 2020, 358, 112623. [CrossRef]

70. Lee, J.; Fung, Y. Flow in Locally Constricted Tubes at Low Reynolds Numbers. J. Appl. Mech. 1970, 37, 9-16. [CrossRef]

71. Caro, C.G.; Fitz-Gerald, J.M.; Schroter, R.C. Atheroma and arterial wall shear. Observation, correlation and proposal of a shear dependent mass transfer mechanism for atherogenesis. Proc. R. Soc. London Ser. B Biol. Sci. 1971, 177, 109-159. [CrossRef]

72. Glagov, S.; Zarins, C.K.; Giddens, D.P.; Ku, D.N. Mechanical Factors in the Pathogenesis, Localization and Evolution of Atherosclerotic Plaques. In Diseases of the Arterial Wall; Springer: Berlin/Heidelberg, Germany, 1989; pp. 217-239. [CrossRef]

73. Ku, D.N.; Giddens, D.P.; Zarins, C.K.; Glagov, S. Pulsatile flow and atherosclerosis in the human carotid bifurcation. Positive correlation between plaque location and low and oscillating shear stress. Arterioscler. Thromb. Vasc. Biol. 1985, 5, $293-302$. [CrossRef]

74. Lodi Rizzini, M.; Gallo, D.; De Nisco, G.; D’Ascenzo, F.; Chiastra, C.; Bocchino, P.P.; Piroli, F.; De Ferrari, G.M.; Morbiducci, U. Does the inflow velocity profile influence physiologically relevant flow patterns in computational hemodynamic models of left anterior descending coronary artery? Med. Eng. Phys. 2020, 82, 58-69. [CrossRef]

75. Biglarian, M.; Larimi, M.M.; Afrouzi, H.H.; Moshfegh, A.; Toghraie, D.; Javadzadegan, A.; Rostami, S.; Momeni, M.; Hassanzadeh H.; Moshfegh, A.; et al. Computational investigation of stenosis in curvature of coronary artery within both dynamic and static models. Comput. Methods Program. Biomed. 2020, 185, 105170. [CrossRef]

76. Kenjereš, S.; van der Krieke, J.P.; Li, C. Endothelium resolving simulations of wall shear-stress dependent mass transfer of LDL in diseased coronary arteries. Comput. Biol. Med. 2019, 114. [CrossRef]

77. Kabir, M.A.; Alam, M.F.; Uddin, M.A. A numerical study on the effects of reynolds number on blood flow with spiral velocity through regular arterial stenosis. Chiang Mai J. Sci. 2018, 45, 2515-2527.

78. Carvalho, V.; Rodrigues, N.; Lima, R.A.; Teixeira, S. Numerical simulation of blood pulsatile flow in stenotic coronary arteries: The effect of turbulence modeling and non-Newtonian assumptions. In Proceedings of the International Conference on Applied Mathematics \& Computer Science, Athens, Greece, 2-4 June 2020.

79. Jahromi, R.; Pakravan, H.A.; Saidi, M.S.; Firoozabadi, B. Primary stenosis progression versus secondary stenosis formation in the left coronary bifurcation: A mechanical point of view. Biocybern. Biomed. Eng. 2019, 39, 188-198. [CrossRef]

80. Liu, B.; Zheng, J.; Bach, R.; Tang, D. Influence of model boundary conditions on blood flow patterns in a patient specific stenotic right coronary artery. Biomed. Eng. Online 2015, 14, S6. [CrossRef] [PubMed]

81. Siogkas, P.K.; Papafaklis, M.I.; Sakellarios, A.I.; Stefanou, K.A.; Bourantas, C.V.; Athanasiou, L.S.; Exarchos, T.P.; Naka, K.K.; Michalis, L.K.; Parodi, O.; et al. Patient-specific simulation of coronary artery pressure measurements: An in vivo threedimensional validation study in humans. Biomed Res. Int. 2014, 2015, 628416. [CrossRef]

82. Zhao, Y.; Ping, J.; Yu, X.; Wu, R.; Sun, C.; Zhang, M. Fractional flow reserve-based 4D hemodynamic simulation of time-resolved blood flow in left anterior descending coronary artery. Clin. Biomech. 2019, 70, 164-169. [CrossRef] [PubMed]

83. Zhang, X.; Luo, M.; Wang, E.; Zheng, L.; Shu, C. Numerical simulation of magnetic nano drug targeting to atherosclerosis: Effect of plaque morphology (stenosis degree and shoulder length). Comput. Methods Program. Biomed. 2020, 195, 105556. [CrossRef] [PubMed] 
84. Lo, E.W.C.; Menezes, L.J.; Torii, R. Impact of inflow boundary conditions on the calculation of CT-based FFR. Fluids $2019,4,60$. [CrossRef]

85. Doutel, E.; Viriato, N.; Carneiro, J.; Campos, J.B.L.M.; Miranda, J.M. Geometrical effects in the hemodynamics of stenotic and non-stenotic left coronary arteries-Numerical and in vitro approaches. Int. J. Numer. Method. Biomed. Eng. 2019, 35, 1-18. [CrossRef]

86. Mahalingam, A.; Gawandalkar, U.U.; Kini, G.; Buradi, A.; Araki, T.; Ikeda, N.; Nicolaides, A.; Laird, J.R.; Saba, L.; Suri, J.S. Numerical analysis of the effect of turbulence transition on the hemodynamic parameters in human coronary arteries. Cardiovasc. Diagn. Ther. 2016, 6, 208-220. [CrossRef]

87. Rabbi, M.F.; Laboni, F.S.; Arafat, M.T. Computational analysis of the coronary artery hemodynamics with different anatomical variations. Inform. Med. Unlocked 2020, 19, 100314. [CrossRef]

88. Malota, Z.; Glowacki, J.; Sadowski, W.; Kostur, M. Numerical analysis of the impact of flow rate, heart rate, vessel geometry, and degree of stenosis on coronary hemodynamic indices. BMC Cardiovasc. Disord. 2018, 18, 1-16. [CrossRef]

89. Chaichana, T.; Sun, Z.; Jewkes, J. Computation of hemodynamics in the left coronary artery with variable angulations. J. Biomech 2011, 44, 1869-1878. [CrossRef]

90. Zhang, J.M.; Zhong, L.; Luo, T.; Huo, Y.; Tan, S.Y.; Wong, A.S.L.; Su, B.; Wan, M.; Zhao, X.; Kassab, G.S.; et al. Numerical simulation and clinical implications of stenosis in coronary blood flow. BioMed Res. Int. 2014, 2014. [CrossRef] [PubMed]

91. Gaudio, L.T.; Caruso, M.V.; De Rosa, S.; Indolfi, C.; Fragomeni, G. Different Blood Flow Models in Coronary Artery Diseases: Effects on hemodynamic parameters. In Proceedings of the Proceedings of the Annual International Conference of the IEEE Engineering in Medicine and Biology Society, Honolulu, HI, USA, 18-21 July 2018; Volume 2018, pp. 3185-3188.

92. Berger, S.A.; Jou, L. Flows in Stenotic Vessels. Annu. Rev. Fluid Mech. 2000, 32, 347-382. [CrossRef]

93. Doutel, E.; Carneiro, J.; Campos, J.B.L.M.; Miranda, J.M. Artificial stenoses for computational hemodynamics. Appl. Math. Model. 2018, 59, 427-440. [CrossRef]

94. Johnston, B.M.; Johnston, P.R.; Corney, S.; Kilpatrick, D. Non-Newtonian blood flow in human right coronary arteries: Steady state simulations. J. Biomech. 2004, 37, 709-720. [CrossRef]

95. Pinto, S.I.S.; Romano, E.; António, C.C.; Sousa, L.C.; Castro, C.F. The impact of non-linear viscoelastic property of blood in right coronary arteries hemodynamics-A numerical implementation. Int. J. Non Linear Mech. 2020, 123, 103477. [CrossRef]

96. Moreno, C.; Bhaganagar, K. Modeling of stenotic coronary artery and implications of plaque morphology on blood flow. Model. Simul. Eng. 2013, 2013, 1-14. [CrossRef]

97. Straatman, A.G.; Ryval, J. Two-equation Turbulence Modeling of Pulsatile Flow in a Stenosed Tube. J. Biomech. Eng. 2016, 126, 625-635. [CrossRef]

98. Ahmadi, M.; Ansari, R. Computational simulation of an artery narrowed by plaque using 3D FSI method: Influence of the plaque angle, non-Newtonian properties of the blood flow and the hyperelastic artery models. Biomed. Phys. Eng. Express 2019, 5, 45037. [CrossRef]

99. Torii, R.; Wood, N.G.; Hadjiloizou, N.; Dowsey, A.W.; Andrew, R.; Hughes, A.D.; Justin, D.; Francis, D.; Mayet, J.; Yang, G.; et al. Fluid-structure interaction analysis of a patient-specific right coronary artery with physiological velocity and pressure waveforms. Commun. Numer. Methods Eng. 2009, 25, 565-580. [CrossRef]

100. Kallekar, L.; Viswanath, C.; Anand, M. Effect of wall flexibility on the deformation during flow in a stenosed coronary artery. Fluids 2017, 2, 16. [CrossRef]

101. Karimi, A.; Navidbakhsh, M.; Razaghi, R.; Haghpanahi, M. A computational fluid-structure interaction model for plaque vulnerability assessment in atherosclerotic human coronary arteries. J. Appl. Phys. 2014, 115. [CrossRef]

102. Van der Giessen, A.G.; Groen, H.C.; Doriot, P.A.; de Feyter, P.J.; van der Steen, A.F.W.; van de Vosse, F.N.; Wentzel, J.J.; Gijsen, F.J.H. The influence of boundary conditions on wall shear stress distribution in patients specific coronary trees. J. Biomech. 2011, 44, 1089-1095. [CrossRef] [PubMed]

103. Wu, W.T.; Li, Y.; Aubry, N.; Massoudi, M.; Antaki, J.F. Numerical simulation of red blood cell-induced platelet transport in saccular aneurysms. Appl. Sci. 2017, 7, 484. [CrossRef]

104. Buradi, A.; Mahalingam, A. Numerical Simulation of Pulsatile Blood Flow in an Idealized Curved Section of a Human Coronary. Int. J. Mech. Prod. Eng. 2016, 2016, 15-19.

105. Buradi, A.; Morab, S.; Mahalingam, A. Effect of stenosis severity on shear-induced diffusion of red blood cells in coronary arteries. J. Mech. Med. Biol. 2019, 19, 1950034. [CrossRef] 